\title{
Introduction
}

\section{A President Falls, Another Collapses}

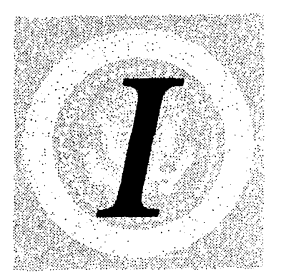

$\mathrm{t}$ was late winter in Florida. The President of the United States had arrived at Hobe Sound shortly after midnight on March I4, 1997, looking forward to a golfing excursion later that day. Golf pro Greg Norman, at whose estate William Jefferson Clinton was staying, gave his guest a tour of his home and then, at I:20 A.M., the President started to depart for his guest cottage. As he walked down a flight of stairs, President Clinton's heel caught on a step, and he stumbled badly. As he fell, his leg snapped so loudly that it was actually heard by his host. Norman caught the President in mid-fall and eased him to the ground, where he sat in great pain. The physician on duty, Dr. William Lang, immediately evaluated the President, treated his injured leg with ice and immobilization, and summoned an ambulance.

Dr. E. Connie Mariano, Senior White House Physician, received the news at her hotel that the President had been injured and she rushed to St. Mary's Hospital in West Palm Beach, arriving there about twenty minutes before he did. At St. Mary's, the President was examined by Dr. Joel Cohen, an orthopedic surgeon. An MRI (Magnetic Resonance Imaging) test showed that while Clinton's bone was not damaged, 90 percent of his right thigh muscle was shredded. Interestingly, during the time when the MRI test was being conducted on the President, a military aide sat just outside the door, holding the codes for unleashing nuclear missiles as well as the presidential succession agreement that had been drawn up between the President and Vice President. In the meantime, both Vice President Gore and his Chief of Staff had been notified of the President's accident. ${ }^{1}$

Dr. Cohen recommended surgery and although Dr. Mariano concurred, she preferred to have the procedure performed in Washington. She had discussed with one of the President's closest aides, Bruce Lindsay, various scenarios under which the Twenty-fifth Amendment should be invoked 
and Vice President Gore made Acting President of the United States. After consulting with Dr. Cohen about the type of anesthesia that leg surgery of this sort would require, she was informed that the procedure is normally performed under epidural (not general) anesthesia. Since the President would be conscious throughout the surgery, Dr. Mariano informed Lindsay that, in her view, the Twenty-fifth Amendment would not apply in this instance.

The President's leg was put in another splint, and he was given a shot of Ketorolac (an injectible anti-inflammatory drug similar to motrin) to ease his pain. At 8 A.M., after periods of fitful sleep, President Clinton was placed in a Secret Service van and taken to the airport. He was carried up the stairs of Air Force One by Secret Service agents while Dr. Lang held his leg in place. The President reportedly had little pain at the time.

As the plane made its way back to Washington, Dr. Mariano instructed Clinton's staff that only family members should see him in the hospital and that he should be spared phone calls and nonessential business. Upon arrival at Andrews Air Force Base, the presidential party left immediately for Bethesda Naval Hospital where the President signed a consent form for surgery. He was given an electrocardiogram and underwent blood work and at I:40 P.M. he was given an epidural injection which made him numb from the waist down but which did not affect his reasoning abilities in any way. Around the same time, an IV was put in his arm for fluids. Surgery commenced at 2:30 P.M. and lasted for two hours and four minutes. The President was awake throughout.

A five-inch longitudinal incision was made by Dr. David Adkison in the President's leg about four inches above the right knee. His muscle-the quadriceps tendon - which had been torn diagonally was sutured together, and the sutures were extended past his tendon into his knee cap. Three holes were drilled in his knee cap and the sutures were attached through them to his knee. When he heard the unpleasant drilling noise, Clinton asked what it was and seemed nonplussed at the answer.

The President was wheeled back to his suite at 5:IO P.M. with the epidural still in place. Dr. Mariano had told him earlier that if at any time he received any medication that would affect his central nervous system, invocation of the Twenty-fifth Amendment would have to be considered. The President responded by instructing his medical team not to give him anything that would make him feel "dopey." Within two hours, Clinton was well enough to speak to the press by speaker phone. On the following day, he taped a speech to the Gridiron Dinner, although his leg pain had begun to increase and an extra dose of Ketorolac had had to be administered to him. 
At I I A.M. on March 16, with no temperature and no sign of infection in his incision, the President was discharged from the hospital. Seated in a wheelchair, he returned to the White House in a van borrowed from Jim Brady, press secretary to Ronald Reagan who was seriously wounded in the $198 \mathrm{I}$ assassination attempt against that President. At the White House, rugs had been taped down in the living quarters and bars installed in the shower (which will remain in place for future Presidents). In order to reduce the swelling, the President's knee was iced down two or three times a day. Also, he began aggressive physical therapy twenty-four hours after his release from the hospital, at first from bed to chair and then on parallel bars and crutches. Not surprisingly, he experienced some pain as he moved his leg, but the President proved to be a very good patient and faithfully followed the regimen laid out for him by his doctors.

On March 19, President Clinton left for a meeting with Russian President Boris Yeltsin in Helsinki. He used a wheelchair there at Dr. Mariano's insistence because crutches tended to tire him out. In Helsinki, he was on blood-thinning medication so that blood clots to the leg would not develop, his leg was elevated, and he continued to get physical therapy which caused him some discomfort. During the week following his return from Finland, the President began working again in the Oval Office. Although pleased that his recovery was proceeding on schedule, he experienced some frustration at being so limited in his activities. He had, after all, been a very mobile Chief Executive and now felt somewhat dejected at his newly restricted lot in life. His travel schedule had to be modified, with trips to Mexico and the rest of Latin America postponed until later in the year. Reportedly, aides worried about the unaccustomed image of a normally robust President being lifted in and out of vehicles, and one of them remarked that "we don't want things looking too FDRish around here." 2

As time passed, however, the President progressed rapidly. He bicycled for 45 minutes every day, guarded against a weight increase by eating smaller portions of food and more fruit, and swam in the White House pool two or three times a week. Finally, on his birthday in August, which he celebrated while vacationing on Martha's Vineyard, Clinton began once again to jog. In September, Dr. Mariano indicated that the President was a full month ahead of schedule in his recovery.

It is interesting to note that although White House officials discussed conditions under which the Twenty-fifth Amendment would be invoked during President Clinton's surgery and subsequent convalescence, it was, in fact, not invoked. Nor was it invoked during the Bush Administration immediately preceding, even though the matter was discussed at that time 
as well and even though those circumstances were even more ominous and unsettling.

In early May I99I, while jogging at Camp David, President Bush suddenly felt unusually fatigued and became short of breath. Accompanied by Secret Service agents, he went immediately to the presidential retreat's infirmary, where Dr. Michael Nash, the physician on duty, found that Bush's heartbeat was irregular. The President left almost immediately by helicopter for Bethesda Naval Hospital for further tests and treatment.

Although the story immediately dominated the news media, medical reports issued by the White House press secretary, Marlin Fitzwater, were uniformly positive. The President had not suffered a heart attack, he had not lost consciousness, he had had no chest pains, he was "entirely stable," and there was no cause for alarm. The President, Fitzwater reported, had even taken his briefcase to the hospital so that he could continue to work. ${ }^{3}$

The President's irregular heartbeat-diagnosed as atrial fibrillationcontinued into the following day, but doctors indicated that the cardiac irregularity represented nothing very unusual or dangerous. One cardiologist suggested, however, that "the sudden appearance of atrial fibrillation in a 66-year-old man . . . has to be taken seriously." 4 The condition might be an indication of an underlying heart problem, possibly a heart attack, or, more likely, a narrowing of the heart's arteries or a damaged heart valve.

Atrial fibrillation is a condition that is not uncommon throughout the United States. It can be caused by stress, exercise, or even excessive caffeine and results in an unusually rapid heartbeat-up to I 50 beats per minute rather than the normal rate of between 60 and roo beats. The condition in itself normally is not life-threatening; but if it continues for a long period, it can lead to the formation of blood clots which may become dislodged and strike the brain. ${ }^{5}$

The news of the President's cardiac condition came as a surprise to a nation that thought of its President as active, vibrant, and robust. Although Bush was the fourth oldest man ever inaugurated as President, he seemed to radiate good health. ${ }^{\star}$ In fact, after a five-hour physical examination in late March I99I, he had received glowing reports from his doctors. His cholesterol levels were described as being within the desirable range, his

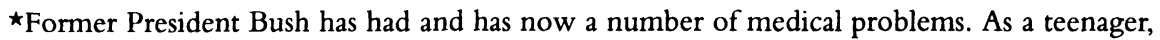
he suffered from hepatitis. He has hay fever, allergies, and mild arthritis of the hips and knees. He has had irritable bowel syndrome; and in 1986 , a small noncancerous polyp was removed from his colon. He has a slightly enlarged prostate and had a small skin cancer removed from his face during his vice presidency. In 1989, a small, benign cyst was removed from one of his fingers; and in 1990 , he was diagnosed as having a mild case of glaucoma. ${ }^{6}$ 
blood pressure was normal, and his blood chemistry tests were said to be satisfactory.

For a man about to turn sixty-seven, the President's medical history gave no real hint of impending heart trouble. Many years before, while he was in his early thirties, Bush had collapsed in a London hotel room, suffering from a bleeding ulcer. He was told by his doctor at the time that he tried to do too much and worried too much and that if he didn't mend his ways, he "wouldn't be around in ten years, maybe five." Bush later wrote that his doctor's blunt words forced him to accept the fact that he couldn't do everything, and that his energy should be directed toward those things that could be accomplished rather than those that could not. ${ }^{7}$ Later, he also found that exercise was helpful in reducing stress and shortly after the age of fifty, began jogging on a regular basis. ${ }^{8}$

Nevertheless, a number of the President's friends indicated that he still internalized a good deal of tension. ${ }^{9}$ Prior to developing atrial fibrillation, Bush appeared fatigued to some associates and upset over news stories that in 1980 he had helped stop U.S. hostages from being released by Iran in order to damage President Carter's re-election campaign. Also, the pressures of the successful Gulf War undoubtedly had taken their toll on the commander in chief, and he was particularly stung by criticism that he had badly mishandled the plight of the Kurdish refugees in Iraq. In other words, Bush had been under greater than usual stress for several months before he was stricken, and his irregular heartbeat may well have reflected this fact.

At Bethesda Naval Hospital, the President underwent an electrocardiogram and ultrasound tests which revealed no structural problems in his heart. By Monday, his heartbeat had returned to normal after digoxin, and then procainamide, were administered to him. Had these medications failed to slow down the President's heart, doctors were considering the use of electrical shocks to achieve this result. Bush would have had to undergo a general anesthetic for a limited period of time, and the shocks would have been used to stop his heart for a moment so that its normal rhythm would resume. According to White House Physician Lawrence Mohr, although this is considered a low-risk procedure, the Twenty-fifth Amendment would have been invoked and Vice President Dan Quayle would have become acting president for a short time. ${ }^{10}$

This thought and, in fact, the entire subject of Quayle's standing just a heartbeat away from the presidency caused considerable distress throughout the country. At the time, Quayle's favorablility rating stood at an abysmal I9 percent, and his competence to handle the office of the presidency was widely questioned, even by Republican party leaders. When Bush returned 
to the White House on 6 May, he tried to bolster his vice president's position by saying that Quayle "has my full support, always has, and he's doing a first class job." 11 The President's words did not reassure the nation, however; nor did they quiet talk that Quayle's place on the 1992 Republican ticket might be in jeopardy.

Shortly after the President's discharge from the hospital, doctors announced that his heart condition had been due to thyroid dysfunction, and surprisingly diagnosed him as having Graves' disease, the same ailment from which his wife, Barbara, suffers. Since the disease is not thought to be contagious, the chances that both husband and wife would have it were estimated at $\mathrm{I}$ in $10,000 .^{12}$

Graves' disease is of unknown origin. Researchers suspect, however, that it may be caused by bacteria and/or stress. Whatever its cause, Graves' disease forces the thyroid gland to become overactive, which, in turn, intensifies the body's metabolism. If untreated, the condition can lead to fever, rapid pulse, breathing difficulties, exhaustion, and even heart failure. ${ }^{13}$

Bush began receiving large doses of radioactive iodine-so large, in fact, that doctors advised him to avoid close contact with family members for several days, in order to avoid exposing them to the radioactivity. The iodine rectifies the thyroid dysfunction, normally within two to six weeks, and the atrial fibrillation tends to disappear. Although the treatment occasionally results in too severe a slowdown in thyroid function, hormone tablets taken on a daily basis usually provide an effective remedy. ${ }^{14}$

Within a short period of time, Bush seemed to return to good health. Eight months later, however, the President's physical condition suddenly and dramatically became the center of news attention once again after he was stricken in Tokyo at a state dinner being given in his honor by Prime Minister Kiishi Miyazawa.

President Bush's visit to Japan was the culmination of a I2-day, 26,000mile journey through the western Pacific to advance the cause of American business and improve the nation's balance of trade. To some of the reporters who were traveling with the President, Bush had occasionally seemed fatigued and out of sorts. ${ }^{15}$ On 8 January, he played a vigorous game of tennis with the American ambassador, the Japanese emperor, and the crown prince and lost badly. By evening, the President did not feel well and summoned his personal physician, Dr. Burton Lee, who diagnosed enteritis (intestinal flu). Since Bush wanted very much to attend the prime minister's state dinner that evening, he ignored his doctor's advice to remain in his quarters, and traveled instead to Miyazawa's official residence. Secret Ser- 
vice agents reportedly were warned, however, that the President might not "make it through the meal." 16 Then, while standing in a receiving line, Bush became quite ill. He excused himself, rushed to a men's room, and vomited. He believed that "that had taken care of" his stomach problems, but soon learned that it "was just the beginning." 17

At 8:20 P.M., as he finished the first course of his meal, the President suddenly became very pale and then fainted. His head dropped to his chest, his body rolled to his left, and he vomited onto his own clothing and that of Prime Minister Miyazawa. The First Lady rushed forward with a napkin which she held to her husband's mouth, and a Secret Service agent leaped onto and over the table to take hold of the President and ease him gently onto the floor. The Japanese prime minister held the President's head in his arms, and aides removed his jacket as the audience stared in shock. Secretary of Commerce Robert Mosbacher, seated near the President, later described the scene as "scary." 18

Within a short time, Bush regained consciousness and, after an interval of several minutes during which he was examined by Dr. Lee, rose to his feet and smiled reassuringly at the relieved and applauding crowd. Immediately, however, he departed from the prime minister's official residence, wearing an overcoat that had been provided by a Secret Service agent to cover his soiled clothing, and returned by limousine to Akasaka Palace, where he was staying during his visit. He was examined there by Dr. Lee and by Dr. Allen Roberts and given an antinausea medication (Tigan). ${ }^{19}$ Although he had a reasonably good night's sleep, he was still somewhat shaky the next morning, and most of the next day's engagements were canceled.

In Washington, the President's press secretary indicated that the White House physician did not believe that any "special monitoring" was necessary, since "all aspects of the examination indicate that it is a common case of the flu." ${ }^{20}$ Nevertheless, an electrocardiogram was administered to the President in order to monitor his heartbeat. It revealed no abnormalities and no return of the irregular heartbeat that had afflicted him eight months earlier. $^{21}$

Gastroenteritis is a common ailment whose sufferers sometimes become severely dehydrated and, after suddenly changing their position (for example, rising to their feet from a sitting position), occasionally faint. Doctors indicate, however, that it is uncommon for sufferers to faint while seated at a table. Dr. Gerald Mandell of the University of Virginia explained that "the fainting at the table puts it in the unusual category because it doesn't happen very often" 22 
The film footage of the President's collapse also fell into the unusual category. Shown over and over again in the United States, the scenes of the President slumping into the arms of the Japanese prime minister struck some as being all too symbolic of the central problem the President had gone to Japan to resolve-an ailing American economy slumping into the "arms" of Japan.

Inevitably, the President's collapse, coming within weeks of the New Hampshire presidential primary, sent political shock waves through the country. One of his aides understated the case when he pointed out that "collapsing and falling under the table in full view is never a political plus for a president." ${ }^{23}$ In addition to Bush's political embarrassment, there were medical concerns as well. Dr. David Benditt, a Minnesota cardiologist, has indicated that patients who are dehydrated, fatigued, or under stress, or who have engaged in physical exercise, may be more susceptible to shortterm fainting spells. ${ }^{24}$ But several life-threatening medical conditions can also provoke this physical reaction. Specifically, a heart attack, a stroke, and/or gastrointestinal bleeding could have been responsible for the President's symptoms. ${ }^{25}$ This fact not only caused concern but also resurrected once again the "Quayle issue."

According to the President's chief of staff, Samuel Skinner, no thought was given at any time to a transfer of power to the vice president. ${ }^{26}$ Quayle had been informed of Bush's sudden illness at 6:20 the following morning. $\mathrm{He}$ later remarked that while he was confident of his ability to become President if necessary, that thought "didn't even cross my mind." 27 The thought of Quayle's ascendancy certainly did cross the minds of other people, however, and provoked another flurry of uneasiness.

President Bush appeared to recover quickly from his embarrassing indisposition and tried hard to downplay the episode. He told reporters, "I don't think there is any political downside," and joked that even "Democrats get the flu." ${ }^{28}$ Bush's campaign strategists had to hope, however, that no further health scare would cast a cloud over his campaign for re-election.

President Bush's medical problems in both I991 and I992 - and President Clinton's in 1997-call renewed attention to the subjects of presidential health, presidential disability, and presidential mortality. The presidency is a tension-filled position, and tension, as I shall discuss in some detail, is intimately related to both illness and death.

In contrast to the many authors who have written about the constitutional and extraconstitutional duties of the American presidency, I focus here on the physical and psychological dangers of the office rather than on its powers and responsibilities. My goal is not only to uncover a sobering 
historical record but also to establish a framework that will explain and refine it. Furthermore, in case studies, I illustrate more specifically the subject of presidential ill health and analyze the impact of ill health on the presidencies of six twentieth-century chief executives-Calvin Coolidge, Franklin Roosevelt, Dwight Eisenhower, John Kennedy, Lyndon Johnson, and Ronald Reagan.

Coolidge died at the age of sixty, just a few years after leaving the White House, where he suffered from debilitating psychological and physical illness. Roosevelt died in office of natural causes at the age of sixty-three, after years of disability and disease. Eisenhower actually exceeded his life expectancy, but endured a life of illness and pain, accentuated during the period of his presidency. Kennedy was assassinated at the age of forty-six, after suffering painful and debilitating illnesses for much of his life. In I96I, he became the youngest man ever elected to the presidency; in 1963, he became the youngest president ever to die in office. Johnson died at the age of sixty-four, four years after leaving the White House and after an adult lifetime filled with painful and dangerous afflictions. And although Reagan, who also exceeded his life expectancy, was sometimes described as having lived a charmed life as the nation's chief executive, his presidency brought him face to face with painful and life-threatening medical crises.

In addition to providing a medical profile for each of these presidents, I shall examine in detail the political effects of their illnesses and medical emergencies and wherever appropriate, construct a psychological "profile" in an effort to provide a broad context for each president's reactions to his disabilities and pain.

Finally, in the concluding chapter, I will explore a number of general implications of presidential illness. Presidential disability comes in a variety of forms, almost all of which were unrecognized and unaddressed by the Framers of the Constitution. Even the Twenty-fifth Amendment, added to the Constitution in 1967, fails to resolve all aspects of the problem. Further work is needed in this important area of public policy. Also, in light of the historical record, new attention must be focused on the vice presidency and efforts made to "upgrade" both the office and the process by which individuals are chosen to fill it. Moreover, consideration should be given to reducing some "presidential pressures" by downsizing his/her responsibilities as chief administrator of the United States. In short, the fact that so many of our presidents have been, to some degree and in some form, disabled must be addressed in terms of both public policy and political practice. I hope that my concluding chapter will at least point out helpful directions in which to move. 



\section{THE MORTAL PRESIDENCY}


